\title{
Isolation of Bioactive Phytochemicals in Leaves of Combretum dolichopentalum and their Hydrogen Peroxide Scavenging Potentials
} Ujowundu FN*, Ukoha Al, Ojiako AO and Nwaoguikpe RN

Department of Biochemistry, Federal University Technology Owerri, Nigeria

\begin{abstract}
This study elucidated the bioactive constituents of leaves of Combretum dolichopentalum. The quantitative phytochemical analyses on the leaves of the plant revealed the presence of alkaloids $(14.24 \pm 2.24 \%)$, flavonoids $(17.00 \pm 2.00 \%)$, tannins $(6.09 \pm 0.32 \%)$, saponin $(4.19 \pm 0.69 \%)$, cyanogenic glycosides $(2.89 \pm 0.22 \%)$, oxalate $(2.56 \pm 0.56 \%)$ and phytate $(0.10 \pm 0.01 \%)$. Further evaluation of the crude plant extract using gas chromatographyflam ionization detector (GC-FID) indicated presence and concentration of specific phytochemicals such as spartein, anthocyanin, lunamarine, epicatechin, rutin, and kaempferol. The free radical scavenging potential of flavonoid, saponins, alkaloid, and tannin precipitated from the plants showed increased scavenging abilities with increasing extract concentration. However flavonoid compared to saponins, alkaloid and tannin showed better scavenging activity with an $\mathrm{IC}_{50}$ of $36.10 \mathrm{mg} / \mathrm{ml}$. These results indicate that $C$. dolichopentalum is endowed with phytoconstituent that has strong antioxidant potencies necessary to provide therapeutic effects.
\end{abstract}

Keywords: Combretum dolichopenta; Gas chromatography; Spartein; Kaempferol; Rutin

\section{Introduction}

The use of medicinal plants as fundamental components of the African traditional health care system is perhaps the oldest and the most assorted of all the therapeutic systems [1]. In many parts of Africa, medicinal plants are the most easily accessible and affordable healthcare resources available to the local communities. Medicinal plants are used and marketed worldwide as herbal drugs or as single active ingredients over centuries. Besides their popular consumption to treat and cure human illness, plant derived natural products play important roles as a source of pharmacological tools to enable the understanding of the biochemical pathways and the etiology of diseases [2]. Plants are sources of potential therapeutic agents against various diseases due to their biodiversity and presence of a wide array of bioactive phytochemicals and secondary metabolites [3]. The use of medicinal plants in the management of diseases is an important alternative therapy widely employed in developing countries. Several investigations have yielded compounds with properties useful for the development of modern synthetic drugs for the management of several diseases [4]. Currently, it is estimated that $80 \%$ of metabolites/plant extracts used as drugs and sold worldwide are derived from natural products and that over 100 new natural product-based lead drugs are in clinical development $[5,6]$. Due to growing drug discovery from natural products, researchers and pharmaceutical industries have increasing interest in traditional health practices used around the world. This interest has been rekindled for decades due to systemic demonstration that plants are the richest source of drugs for traditional system of medicine, modern medicines, nutraceuticals, food supplements, folk medicines, pharmaceutical intermediates and chemical entities for synthetic drugs [7]. The pharmaceutical effects of plant are due to the presence of phytoconstituents called phytochemicals. Phytochemicals are biological active, naturally occurring secondary compounds found in plants, which provide health benefits for humans further than those attributed to macronutrients and micronutrients [8].

Phytochemicals have biological properties, such as antioxidant activity [9], antimicrobial effect [10,11], and are associated with a lower incidence of heart disease, ischemic stroke, and other chronic diseases [12-16]. Phytochemicals can detoxify substances that cause cancer, by neutralizing free radicals, inhibiting enzymes that activate carcinogens and also activate enzymes that detoxify carcinogens $[17,18]$.

Combretum dolichopentalum is used in treating disease conditions of the alimentary tract is used for the treatment of stomach ache, gastro intestinal disorders, such as dysentery, passage of bloody stool, diarrhea and stomach ulcer and reconditioning of the uterus after parturition by mother in Ibo ethnomedicine especially in Ezinihitte Mbaise and other Mbaise ethnic nationality of Imo State. The leaves are cooked until the fluid content turns red, and is prepared as soup for drinking [19]. According to the free radical theory of ageing, senescence and a variety of degenerative diseases associated with it are attributed to the deleterious attack of oxygen free radicals on cellular constituents, including connective tissues, chromosomes and mitochondrial DNA [20-22]. Unsaturated fatty acids of cellular membranes are biomolecules most susceptible to oxidative damage in cells, and this sensitivity increases as a function of their double bonds. Lipid peroxidation is mainly initiated by hydrogen abstractions from unsaturated fatty acids by oxygen centred radicals followed by the formation of hydroperoxides. Degradation of hydroperoxides results in a variety of derivatives including various carbonyl products [20-23]. Such unsaturated carbonyls include enals, dienals, trienals, hydroxylenals, 2-ketoaldehydes, deoxyosones and various reductions that are very reactive and toxic to almost all cellular and extracellular biomolecules $[20,24,25]$. Therefore this research is targeted at providing information on the phytoconstituents of leaves of $C$. dolichopentalum and their radical scavenging capacity.

*Corresponding author: Ujowundu FN, Department of Biochemistry, Federa University Technology, PMB, Owerri, Ihiagwa, Nigeria, Tel: +234 (083) 230974 E-mail: fnujowundu@yahoo.com

Received October 14, 2015; Accepted November 05, 2015; Published November 09, 2015

Citation: Ujowundu FN, Ukoha Al, Ojiako AO, Nwaoguikpe RN (2015) Isolation of Bioactive Phytochemicals in Leaves of Combretum dolichopentalum and their Hydrogen Peroxide Scavenging Potentials. Pharm Anal Acta 6: 444 doi:10.4172/21532435.1000444

Copyright: (C) 2015 Ujowundu FN, et al. This is an open-access article distributed under the terms of the Creative Commons Attribution License, which permits unrestricted use, distribution, and reproduction in any medium, provided the original author and source are credited. 


\section{Materials and Method}

\section{Plant sample}

Fresh leaves of $C$. dolichopentalum were harvested from farms in Obinze in Owerri West Local Government Area of Imo state. The plant was authenticated by Mr Ozioko, of the Bioresource Development and Conservation Program (BDCP), Research Centre, university of Nigeria Nsukka, Enugu State Nigeria.

\section{Phytochemical analyses}

Quantitative phytochemical screening and isolation was done using the procedures outlined by Harborne [26], Trease and Evans [27], Obadoni and Ochuko [28].

Phytochemical analyses using gas chromatography fitted with flame ionization detector (GC-FID) was also carried out on the plant to reveal specific phytochemicals. Briefly; the dried sample $(20 \mathrm{~g})$ was soaked for 72 hours in ethyl acetate. The filtrate was concentrated under reduced pressure, using rotary evaporator at a maximum temperature of $45^{\circ} \mathrm{C}$ to yield $1 \mathrm{~g}$ crude extracts. The ethyl acetate extract $(1 \mathrm{~g})$ was subjected to Thin Layer Chromatography (TLC), eluted with ethylacetate. The pure samples from the TLC were dissolved in ethyl acetate and 1 microliter was subjected to GC analysis for phytochemical determination.

\section{Fixed settings}

Instrument: Buck 530 gas chromatograph equipped with an on-column automatic injector, flame ionization detector, HP 88 capillary column ( $100 \mathrm{~m} \times 0.25 \mu \mathrm{m}$ film thickness,) CA, USA. Detector temperature was set at $250^{\circ} \mathrm{C}$ and both injectors temperatures were held at $220^{\circ} \mathrm{C}$. The integrator chart speed was maintained at $2 \mathrm{~cm} / \mathrm{min}$ and oven temperature was set at $180^{\circ} \mathrm{C}$ and the GC was allow to warm up. While it was warming, instrument final temperature was set to $220^{\circ} \mathrm{C}$ and was allowed to run for 45 mins and ramped for $15 \mathrm{mins}$ at a rate of $0^{\circ} \mathrm{C} / \mathrm{min}$. The analysis was started by the injection of $1.0 \mu \mathrm{l}$ sample onto column A using the appropriate injection technique.

Alkaloid extraction: Alkaloid was extracted as described by Obadoni and Ochuko [28]. Briefly; Fifty grams (50 g) of the sample was weighed into a $1000 \mathrm{ml}$ beaker and $500 \mathrm{ml}$ of $29 \%$ acetic acid in ethanol was added and allowed to stand for $6 \mathrm{hrs}$. This was filtered and the filtrate concentrated on a rotary evaporator to one quarter of the original volume. The alkaloid was precipitated out using concentrated ammonium hydroxide which was added drop by drop until precipitate was complete. The solution was allowed to settle and the precipitation was collected by filtration using Whatman No. 1 filter paper. The precipitate obtained was tested for the presence of alkaloid using standard methods [26,27].

Saponin extraction: Saponin was extracted as described by Obadoni and Ochuko [28]. Briefly; Fifty grams (50 g) of the sample was weighed into a $1000 \mathrm{ml}$ beaker and $500 \mathrm{ml}$ of $20 \%$ ethanol was added and stirred using a glass rod. The mixture was heated over water bath for $4 \mathrm{hrs}$ with continuous stirring while the temperature was maintained at $55^{\circ} \mathrm{C}$. The mixture was filtered and the residue was re-extracted with $500 \mathrm{ml}$ of $20 \%$ ethanol. The combined extract was reduced to $40 \mathrm{ml}$ on a rotary evaporator. The concentrated extract was transferred into a $250 \mathrm{ml}$ separation funnel and $50 \mathrm{ml}$ of diethyl ether was added and shaken vigorously. The aqueous layer was recovered while the ether layer was discarded. This process was repeated thrice and finally $60 \mathrm{ml}$ of $\mathrm{n}$-butanol was added. The mixture was washed twice with a $10 \mathrm{ml}$ of $5 \%$ sodium chloride. The remaining solution was heated over water bath and the residue dried to constant weight. The precipitate obtained was tested for presence of saponin using standard methods [26,27].

Flavonoid extraction: Flavonoid was extracted as described Boham and Kocipai [29]. Briefly; Fifty grams (50 g) of the plant sample were extracted repeatedly with $500 \mathrm{ml}$ of $80 \%$ aqueous methanol at room temperature. The solution obtained was filtered with Whatman No. 45 filter paper. The combined filtrate was concentrated on a rotary evaporator. The precipitate obtained was tested for presence of flavonoid using standard methods [26,27].

Tannin extraction: Tannin was extracted by the method described by the International Oenological Codex, [30]. Briefly; Fifty grams $(50 \mathrm{~g})$ of the plant sample was extracted with $500 \mathrm{ml}$ of water. The aqueous extract was extracted thrice with ethyl acetate to eliminate neutral substances. The extract was brought to $\mathrm{pH} 2$ by the addition of concentrated $\mathrm{HCl}$ and re-extracted with ethyl acetate. The extract was concentrated on a rotary evaporator. The extract was tested for the presence of tannin using standard methods $[26,27]$.

\section{Radical scavenging/antioxidant studies}

Hydrogen peroxide scavenging activity by flavonoid, alkaloids, saponins and tannins isolated from leaves of $C$. dolichopentalum was estimated by the method of Ruch et al. [31]. Each isolate (flavonoid, alkaloids, saponins and tannins) from C. dolichopentalum was dissolved in distilled water at various concentrations, mixed with 0.1 $\mathrm{M}$ phosphate buffer ( $\mathrm{pH} 7.4$ ) and $0.6 \mathrm{ml}$ of $4 \mathrm{mM}$ hydrogen peroxide solution prepared with the same buffer and incubated for 10 mins. The absorbance of each reaction mixture was recorded at $230 \mathrm{~nm}$ against blank solution containing the plant extract without $\mathrm{H}_{2} \mathrm{O}_{2}$. The amount of $\mathrm{H}_{2} \mathrm{O}_{2}$ inhibited by the isolates (flavonoid, alkaloids, saponins and tannins) were calculated using the following equation:

$\mathrm{H}_{2} \mathrm{O}_{2}$-scavenging capacity $=\left[\left(\underline{\text { Abscontrol-Abs }}_{\text {sample }}\right) /\left(\mathrm{Abs}_{\text {control }}\right)\right] \times 100$

Where: $\mathrm{Abs}_{\text {control }}$ is the absorbance of $\mathrm{H}_{2} \mathrm{O}_{2}$ radical+methanol;

Abs $_{\text {sample }}$ is the absorbance of $\mathrm{H}_{2} \mathrm{O}_{2}$ radical+sample isolate or standard.

\section{Statistical Analyses}

Data obtained were presented in mean \pm standard deviation and simple percentages of triplicate determination

\section{Results}

Quantitative phytochemical screening (Table 1) of C. dolichopentalum leaves indicates the presence of flavonoid, alkaloid, saponins, tannins, cyanogenic glycosides, oxalate, and phytate. The analyses carried out on the sample revealed high concentrations of flavonoids $(17.00 \pm$ $2.24 \%)$, alkaloids (14.24 $\pm 4 \%)$, saponins ( $4.19 \pm 0.69 \%)$, and tannins $(6.09 \pm 0.32 \%)$. Results of GC-FID (Table 2 and Figure 1) shows the presence of flavonoids like kaempferol $(25.1564 \mu \mathrm{g} / \mathrm{ml})$, Rutin $(263.249$ $\mu \mathrm{g} / \mathrm{ml})$; Anthrocyanin $(0.5854 \mu \mathrm{g} / \mathrm{ml})$, and epicatechin $(6.5163 \mu \mathrm{g} /$ $\mathrm{ml})$. Other phytochemicals identified where Lunamarine $(5.9893 \mu \mathrm{g} /$ $\mathrm{ml})$, Oxalate $(1.179 \mu \mathrm{g} / \mathrm{ml})$, Tannin $(16.0476 \mu \mathrm{g} / \mathrm{ml})$ and alkaloids like Sparteine $(0.0021 \mu \mathrm{g} / \mathrm{ml})$. Result (Table 3 and Figure 2) showed that Flavonoid, saponins, alkaloid, and tannin scavenging abilities increased with increase extract concentration. However Flavonoid compared to saponins, alkaloid and tannin showed better scavenging activity with a $50 \%$ inhibition concentration $\left(\mathrm{IC}_{50}\right.$ ) of $36.10 \mathrm{mg} / \mathrm{ml}, \mathrm{R}^{2}$ of 0.94 . Saponin showed $\mathrm{IC}_{50}$ of $126.25 \mathrm{mg} / \mathrm{ml}, \mathrm{R}^{2}$ of 0.97 , while alkaloid had $\mathrm{IC}_{50}$ of 61.18 
Citation: Ujowundu FN, Ukoha Al, Ojiako AO, Nwaoguikpe RN (2015) Isolation of Bioactive Phytochemicals in Leaves of Combretum dolichopentalum and their Hydrogen Peroxide Scavenging Potentials. Pharm Anal Acta 6: 444. doi:10.4172/21532435.1000444

Page 3 of 6

$\mathrm{mg} / \mathrm{ml}, \mathrm{R}^{2}$ of 0.94 and tannin had $\mathrm{IC}_{50}$ of $55.56 \mathrm{mg} / \mathrm{ml}, \mathrm{R}^{2}$ of 0.97 .

\section{Discussion}

Phytochemicals provide health benefits further than those attributed to macronutrients and micronutrients [8]. Appreciable amount of

\begin{tabular}{|c|c|}
\hline Phytochemicals (Quantitative) & \% Concentration \\
\hline Alkaloids & $14.24 \pm 2.24$ \\
\hline Flavonoids & $17.00 \pm 2.00$ \\
\hline Tannins & $6.09 \pm 0.32$ \\
\hline Saponins & $4.19 \pm 0.69$ \\
\hline Cyanogenic Glycosides & $2.89 \pm 0.22$ \\
\hline Oxalate & $2.56 \pm 0.56$ \\
\hline Phytate & $0.10 \pm 0.01$ \\
\hline
\end{tabular}

Values are mean \pm standard deviation of triplicate determinations

Table 1: Phytochemical composition of $C$. dolichopentalum leaves.

\begin{tabular}{|c|c|c|c|c|}
\hline $\begin{array}{c}\text { Name of } \\
\text { Phytochemical }(\boldsymbol{\mu g} / \mathbf{m l})\end{array}$ & $\begin{array}{c}\text { Retention } \\
(\mathbf{m i n})\end{array}$ & Area $\left.\mathbf{( m}^{2}\right)$ & $\begin{array}{c}\text { Peak Height } \\
\mathbf{( m )}\end{array}$ & $\begin{array}{c}\text { Concentration } \\
(\boldsymbol{\mu} \mathbf{g} / \mathbf{m} \mathbf{)})\end{array}$ \\
\hline Spartein & 0.206 & 3284.7296 & 214.708 & 0.0021 \\
\hline Oxalate & 5.726 & 6278.2144 & 356.512 & 1.179 \\
\hline Anthrocyanin & 10.266 & 2928.024 & 166.381 & 0.5854 \\
\hline Tannin & 14.496 & 3543.6292 & 201.37 & 16.0476 \\
\hline Lunamarine & 19.033 & 3618.428 & 204.623 & 5.9893 \\
\hline Epicatechin & 32.55 & 3220.2098 & 183.068 & 6.5163 \\
\hline Rutin & 37.41 & 4478.5715 & 254.444 & 65.2853 \\
\hline Rutin & 41.91 & 13580.3106 & 758.567 & 197.9637 \\
\hline Kaempferol & 41.91 & 5322.8864 & 302.256 & 25.1564 \\
\hline Total & & 46255.0035 & & 318.725 \\
\hline
\end{tabular}

Table 2: Identification of phytochemical content of $C$. dolichopentalum leaves using gas chromatography. saponins, flavonoids, and tannins were observed in the leaves of $C$. dolichopentalum. Saponins are known to exert anticholesterolemic and hypoglycaemic effect through intra-lumenal physiochemical interaction or other yet unidentified activities [32]. Saponins have also been observed to protect plants from protozoans and molluscs and also act as antifungal and antiviral agents [33,34].

The leaves of $C$. dolichopentalum contain flavonoids of the type; kaempferol, rutin, anthocyanin and epicatechin in varying concentration (Table 2 and Figure 1). At cellular levels, flavonoids have been found to exert a variety of biological effects [35], presumably mediated by specific interaction with molecular targets [36-38]. The capacity of flavonoids to act as antioxidant depends on their molecular structure. The position of $\mathrm{OH}$ groups and other features are important for flavonoids antioxidant and free radical scavenging activities.

Kaempferol is under consideration as a possible cancer treatment [39-41], because it reduces the resistance of cancer cells to anti-cancer drugs such as Vinblastine and paclitaxel [42]. This is to say that extract from C. dolichopentalum could function as an anticancer drug. Anthocyanins has been reported to be involved in the improvement of vision, inhibition of nitric oxide product, induction of apoptosis, decreased platelet aggregation, and neuroprotective effects [43]. A recent study has reported anthocyanin to have outstanding antisickling effects [44]. Rutin, also called rutinoside, quercetin-3O-rutinoside and sophorin, is the glycoside between the flavonol quercetin and the dissacharide rutinoside. Rutin has been reported to contribute to antimicrobial [45], and antioxidant [46] properties of plant. Furthermore, it has been shown to inhibit in vitro, the vascular endothelial growth factor [47] in sub-toxic concentrations, so acts as an inhibitor of angiogenesis. This finding may have potential relevance for the control and management of some cancers.

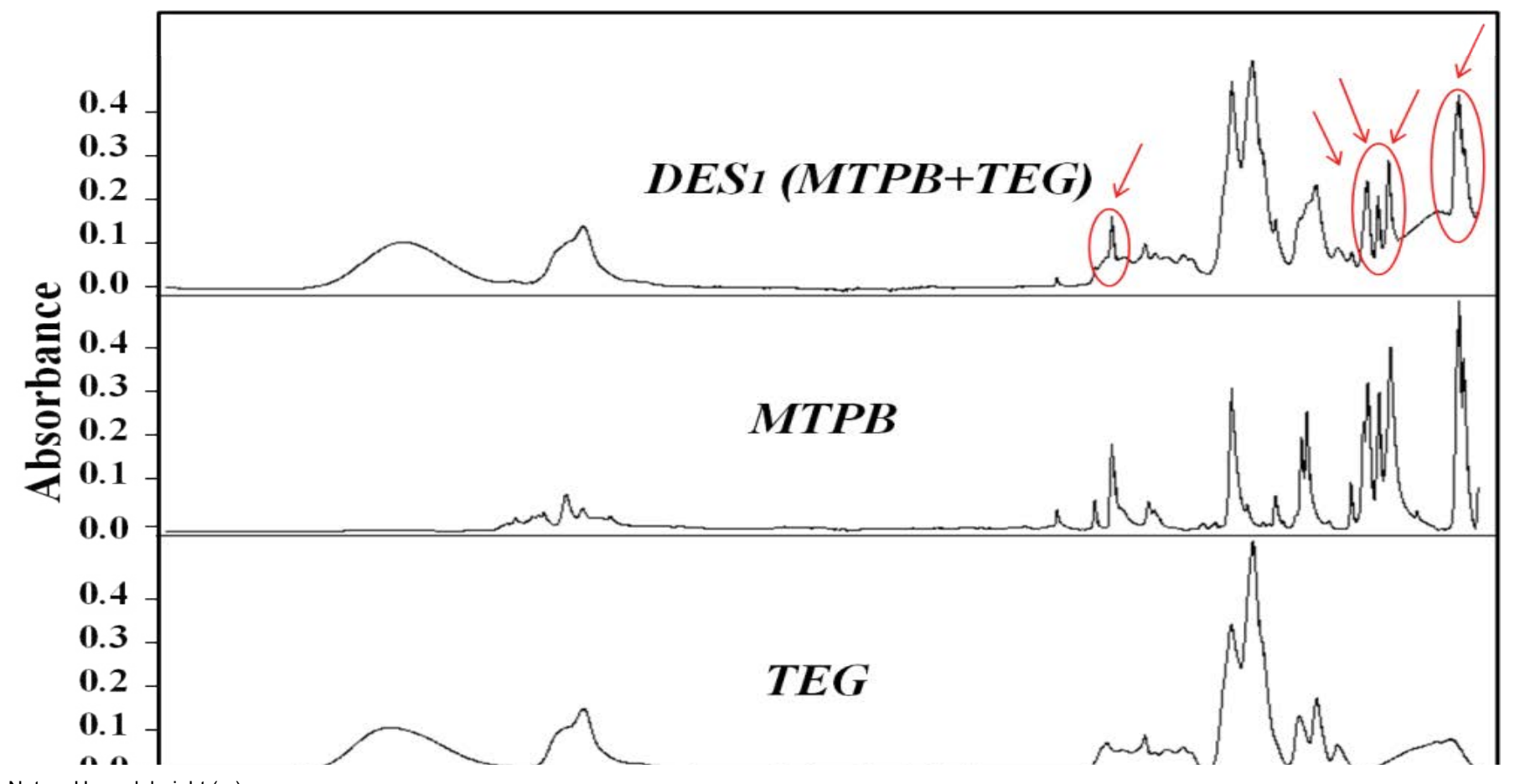

Note: $\mathrm{pH}=$ peak height $(\mathrm{m})$

Figure 1: Chromatogram of phytochemicals in he leaves of $C$. dolichopentalum. 


\begin{tabular}{|c|c|c|c|c|}
\hline \multirow{2}{*}{$\begin{array}{c}\text { Concentration } \\
(\mathbf{m g} / \mathbf{m l})\end{array}$} & \multicolumn{4}{|c|}{$\%$ inhibition by isolates } \\
\cline { 2 - 5 } & Flavonoid & Saponin & Tannin & Alkaloid \\
\hline 0 & 0 & 0 & 0 & 0 \\
\hline 5 & $2.67 \pm 0.12$ & $3.51 \pm 0.48$ & $9.27 \pm 1.02$ & $1.19 \pm 0.12$ \\
\hline 10 & $13.37 \pm 2.33$ & $7.02 \pm 0.78$ & $12.25 \pm 2.02$ & $12.30 \pm 1.20$ \\
\hline 15 & $28.09 \pm 3.60$ & $8.77 \pm 0.42$ & $23.84 \pm 1.22$ & $13.09 \pm 0.98$ \\
\hline 20 & $31.43 \pm 3.23$ & $14.47 \pm 2.02$ & $28.48 \pm 2.22$ & $24.60 \pm 2.04$ \\
\hline 25 & $43.48 \pm 4.33$ & $18.42 \pm 0.45$ & $30.13 \pm 2.01$ & $28.97 \pm 1.34$ \\
\hline $\mathrm{IC}_{50}$ & 36.1 & 126.25 & 55.56 & 61.18 \\
\hline $\mathrm{r}^{2}$ & 0.94 & 0.97 & 0.966 & 0.94 \\
\hline
\end{tabular}

Table 3: Summary of hydrogen peroxide radical scavenging activity of major phytochemicals from $C$. dolichopentalum.

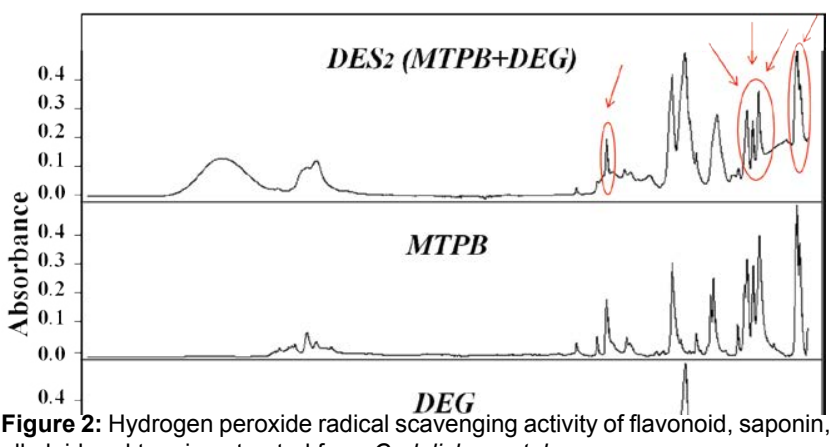

alkaloid and tannin extracted from C. dolichopentalum.

The physiological effects of alkaloids have made them important compounds in medicine. They have been used as pain killers (Morphine), stimulants (Caffeine), muscle relaxers (Cocaine), tranquilizers (Curare), anti-cancer (Vincristine, Vinplastine), anaesthetics (Cocaine), antiarrythmias (Quanidine), Vaso-constrictors (Ergonovine, Ephedrine), antimalarial (Quinine), poisons (Tobocurarine, coniine, strychinine), pupil expander (Atropine) and hallucinogenic drugs (mescaline) [4851]. Our screening showed that $C$. dolichopentalum leaves contain alkaloids such as spartein. Sparteine is a quinolizidine alkaloid which has been reported to exhibit antiarrhythmic properties. Spartein was once used as a uterus contracting drug, but now abandoned because of its side effect. Spartein has also been reported to have hypotensive and CNS depressant properties and furthermore, are hypoglycemic and thus C. dolichopentalum can be exploited for anti-diabetic drugs [52]. Lunamarine is a quinoline alkaloid. Lunamarine has shown anticancer [53], anti-estrogenic [54], immunomodulatry [55], and anti-amoebic activity particularly against Entamoeba histolycal [56]. This indicates the use of $C$. dolichopentalum for the treatment of stomach ache, gastro intestinal disorders, such as dysentery, passage of bloody stool, and diarrhea.

Tannic acid was indentified in C. dolichopentalum leaves in high concentrations. Tannins are known to tar the outermost layer of the mucosa [57] and thereby render it less permeable and more resistant to chemical and mechanical injury or irritation. According to [57], tannins are used as astringent or antidote for various poisons and as a tropical haemostatic. Tannins have antioxidant, antimicrobial [58], anticancer [59], activities. Tannic acid is reported to have antihypertensive, antidiarrheal, anti-asthmatic, cardioprotective, antidiabetic, anti-cataractogenic, tumour inhibition, anti-inflamatory, and anti-adipogenic [59], and hepatoprotective [60] activities.

The leaves of $C$. dolichopentalum showed low concentration of phytate and oxalate. Phytate is a hexaphosphate ester of inisitol that is widely distributed in vegetables. It is considered an antinutrient because of the possibility of its interference with proteolytic digestion, in addition to the fact that the phosphorus in it is not nutritionally available to monogastric animals [61]. It is considered an antinutritional factor because it complexes with nutritionally essential divalent cations like $\mathrm{Ca}^{2+}, \mathrm{Fe}^{2+}, \mathrm{Mg}^{2+}$ and $\mathrm{Zn}^{2+}$, thus rendering them unavailable from the diet. It is therefore advisable to use the leaves with mineral supplements. Results also showed that phytate in the plant leaves was higher than that found in Sphenostylis stenocarpa $0.42 \%$; Citrullus colocythis, $0.64 \%$, Pentochethra macrophylla, 0.36\%; Muanna flagellipes, $0.33 \%$ [62]. Oxalate like phytate, has the ability to bind some divalent metal ions such as $\mathrm{Ca}^{2+}$ and $\mathrm{Mg}^{2+}$, thereby interfering with their metabolism. Ingestion of an excessive amount of oxalate could cause muscular weakness or paralysis, hypocalcaemia, development of urinary calculi, blockage of the renal tubules by calcium oxalate crystals and gastrointestinal irritation.

Plant phytochemicals have antioxidant activities [8,9], exhibited by neutralizing reactive oxygen species, inhibiting and/or activating enzymes systems for free radical scavenging. Hydrogen peroxide $\left(\mathrm{H}_{2} \mathrm{O}_{2}\right)$ is an important reactive oxygen species, because of its ability to penetrate biological membranes and its ability to form hydroxyl radicals in cells. It reacts with $\mathrm{Fe}^{++}$or $\mathrm{Cu}^{++}$ions [63] in a reaction called Fenton-Haber Weiss reaction. The results of the hydrogen peroxide scavenging ability of the phytochemical extract of $C$. dolichopentalum leaves were remarkable. The flavonoid, saponins, alkaloid and tannins precipitated from leaves of $C$. dolichopentalum scavenged $\mathrm{H}_{2} \mathrm{O}_{2}$ in a dose dependent manner. Also, the scavenging ability of flavonoid was higher compared to saponins, alkaloid and tannin from C. dolichopentalum. Polyhydroxylated compounds like flavonoids are known to possess high antioxidant activity. This activity could be due to flavonoid ability to absorb, neutralize and scavenge free radicals [64]. The presence of hydroxyl groups attached to the aromatic ring structures of flavonoid also confers it radical scavenging ability.

Kaempferol- a subfamily of flavonoid has been reported to scavenge $\mathrm{H}_{2} \mathrm{O}_{2}$ [40]. These effects indicate the possibility of $C$. dolichopentalum to minimize oxidative damage to some vital tissues and organs when used therapeutically. The low level of scavenging ability of alkaloid compared to flavonoid and tannin precipitated from $C$. dolichopentalum may be due to the solubility of alkaloid in the test medium and substrate used may influence the ability of a compound to scavenge different radicals [65]. A dose response relationship exist when changes in dose produce consistent, non random changes in effect either in the magnitude of the effects or in the percent of individuals responding at a particular level of effect.

According to the A.J. Clarke occupation theory, the intensity of drug action is proportional to the occupancy of the receptors or the concentration of the drug-receptor complexes [66,67]. But there are drugs that do not act through specific receptors either in vivo or in vitro; example includes anaesthetics and antioxidant which can be local or general. Antioxidants including those found in phytochemicals are made up of subfamilies with different structures. It is this structure that confers radical scavenging abilities on them. For instance, flavonoids are made up kaempferol, luteolin, apigenin, isorhamnetin, resveratrol, quercetin, epicatechin etc., with different potencies in scavenging radicals. Thus at different concentrations, a particular subfamily with less free- radical scavenging potentials, can actively engage in radical scavenging exercise resulting in a lower \% inhibition. 
Citation: Ujowundu FN, Ukoha Al, Ojiako AO, Nwaoguikpe RN (2015) Isolation of Bioactive Phytochemicals in Leaves of Combretum dolichopentalum and their Hydrogen Peroxide Scavenging Potentials. Pharm Anal Acta 6: 444. doi:10.4172/21532435.1000444

\section{Conclusion}

The presence of bioactive flavonoids, alkaloids, saponin and tannins with pharmacological properties suggest that $C$. dolichopentalum possess antioxidant, anti-inflammatory, antiarrythmic, anticancer, and hypotensive properties. The presence of lunamarine confers anti amoebic activities in the plant, and this may be why natives of Mbaise and Ogwa of Imo state in Nigeria, use this plant to treat gastrointestinal disorders. Furthermore, the ability of the plant to scavenge hydrogen peroxide which can subsequently form hydroxyl radical in a fentonHaber weiss reaction in vitro, suggest that $C$. dolichopentalum may as well possess the ability, to scavenge different radicals, especially the flavonoid extract from the plant.

\section{Acknowledgment}

The authors appreciate the technical support and contribution of $\mathrm{Dr}$. Cosmas O. Ujowundu of Department of Biochemistry, Federal University Technology Owerri, Nigeria.

\section{References}

1. Mahomoodally MF (2013) Traditional medicines in Africa: an appraisal of ten potent African medicinal plants. Evid Based Complement Alternat Med 2013: 617459.

2. Rishton GM (2008) Natural products as a robust source of new drugs and drug leads: past successes and present day issues. Am J Cardiol 101: 43D-49D.

3. Farombi EO (2003) African Indigenous Plants with Chemotherapeutic Potentials and Biotechnological Approach to the Production of Bioactive Prophylactic Agents. Afr J Biotechnol 2: 662-671.

4. Iweala EEJ, Uchegbu FO, Adesenoya OA (2013) Biochemical Effects of Leaf Extracts of Gongronema latifolium and Selenium Supplementation in Aloxaninduced Diabetes Rats. Journal of pharmacognosy and phytotherapy 5: 91-97.

5. Butler MS (2008) Natural products to drugs: natural product-derived compounds in clinical trials. Nat Prod Rep 25: 475-516.

6. Bhutani KK, Gohil VM (2010) Natural products drug discovery research in India: status and appraisal. Indian J Exp Biol 48: 199-207.

7. Hammer KA, Carson CF, Riley TV (1999) Antimicrobial activity of essential oils and other plant extracts. J Appl Microbiol 86: 985-990.

8. Hasler CM, Blumberg JB (1999) Phytochemicals: biochemistry and physiology Introduction. J Nutr 129: 756S-757S.

9. Rahman MM, Habib MR, Hasan MA, Al Amin M, Saha A, et al. (2014) Comparative assessment on in vitro antioxidant activities of ethano extracts of Averrhoa bilimbi, Gymnema sylvestre and Capsicum frutescens. Pharmacognosy Research 6: 36-41.

10. Gibson EL, Wardle J, Watts CJ (1998) Fruit and vegetable consumption, nutritional knowledge and beliefs in mothers and children. Appetite 31: 205-228.

11. Alisi CS, Onyeze GOC (2008) Nitric Oxide Scavenging Ability Fraction of Methanolic Leaf Extracts of Chromolena odorata (Linn). African Journal Biochemistry Research 2: 145-150.

12. Verlangieri AJ, Kapeghian JC, el-Dean S, Bush M (1985) Fruit and vegetable consumption and cardiovascular mortality. Med Hypotheses 16: 7-15.

13. Joshipura KJ, Ascherio A, Manson JE, Stampfer MJ, Rimm EB, et al. (1999) Fruit and vegetable intake in relation to risk of ischemic stroke. JAMA 282: 1233-1239.

14. Riboli E, Norat T (2003) Epidemiologic evidence of the protective effect of fruit and vegetables on cancer risk. Am J Clin Nutr 78: 559S-569S.

15. Peterson J, Lagiou P, Samoli E, Lagiou A, Katsouyanni K, et al. (2003) Flavonoid intake and breast cancer risk: a case--control study in Greece. $\mathrm{Br} J$ Cancer 89: 1255-1259.

16. Bosetti C, Spertini L, Parpinel M, Gnagnarella P, Lagiou P, et al. (2005) Flavonoids and breast cancer risk in Italy. Cancer Epidemiol Biomarkers Prev 14: $805-808$

17. Meagher E, Thomson C (1999) Vitamin and Mineral Therapy. In Medical Nutrition and Disease, 2nd ed., G Morrison and L Hark, Malden, Massachusetts: Blackwell Science Inc 33- 58.
18. Rao BN (2003) Bioactive phytochemicals in Indian foods and their potential in health promotion and disease prevention. Asia Pac J Clin Nutr 12: 9-22.

19. Asuzu IU, Onu OU (1988) Anti-ulcer activity of the Ethanol Extract of Combretum dolichopentalum Root. Journal Crude Drug Res 25: 44 - 48.

20. Esterbauer H, Schaur RJ, Zollner H (1991) Chemistry and Biochemistry of 4-hydroxy-nonenal, malondialdehyde and related aldehydes. Free Radical Biol. Med 11:81-121.

21. Halliwell B, Gutteridge JMC (1999) Free Radicals in Biology and Medicine. 3rd ed. Oxford University Press, New York.

22. Stadtman ER, Berlett BS (1998) Reactive oxygen-mediated protein oxidation in aging and disease. Drug Metab Rev 30: 225-243.

23. Schauenstein E, Esterbauer $H$ (1978) Formation and properties of reactive aldehydes. Ciba Found Symp: 225-244.

24. Yin D, Brunk UF (1995) Carbonyl toxification hypothesis of biological aging In: Macieira-Coelho, A. (Ed.), Molecular Basis of Aging. CRC Press, Inc., New York 421-436.

25. Baynes JW (2000) From life to death--the struggle between chemistry and biology during aging: the Maillard reaction as an amplifier of genomic damage. Biogerontology 1: 235-246.

26. Harborne JB (1984) Phytochemical Method. A Guide to Modern Technique of Plant Analysis. London: Chapman and Hall 54-60.

27. Trease GE, Evans MC (1989) "Textbook of Pharmacognosy," 13th ed. Bailiere Tindall 200: 201, 304-348, 419-423, 626-630, 765-775.

28. Obadoni PO, Ochuko MC (2001) Practical methods of determining various components from plant extract. Advance in Environmental Medicine and Biology 102: 341-398.

29. Boham BA, Kocipai-Abyazan R (1974) Flavonoids and condensed tannins from leaves of Hawaiian vaccinium vaticulatum and V. calycinium. Pacific Sci 48 : 458-463.

30. International Oenological CODEX (2009) Oenological Tannins INS N: 181 Oeno 12/2002 modified by Oeno 5/2008, 6/2008 and OIV-Oeno 352-2009

31. Ruch RJ, Cheng SJ, Klaunig JE (1989) Prevention of cytotoxicity and inhibition of intercellular communication by antioxidant catechins isolated from Chinese green tea. Carcinogenesis 10: 1003-1008

32. Price KR, Johnson IT, Fenwick GR (1987) The chemistry and biological significance of saponins in foods and feeding stuffs. Crit Rev Food Sci Nutr 26: $27-135$.

33. Lacaille - Dubois MA, Wagner H (2000) Bioactive saponin from plants: An update. Studies in Natural Products Chemistry, Atta - Ur - Rahman ed. Elsevier Science. Amsterdam 21: 633-687.

34. Traore F, Faure R, Ollivier E, Gasquet M, Azas N, et al. (2000) Structure and antiprotozoal activity of triterpenoid saponins from Glinus oppositifolius. Planta Med 66: 368-371.

35. Middleton E Jr, Kandaswami C, Theoharides TC (2000) The effects of plant flavonoids on mammalian cells: implications for inflammation, heart disease, and cancer. Pharmacol Rev 52: 673-751.

36. Kanakis CD, Tarantilis PA, Polissiou MG, Diamantoglou S, Tajmir-Riahi HA (2005) DNA interaction with naturally occurring antioxidant flavonoids quercetin kaempferol, and delphinidin. J Biomol Struct Dyn 22: 719-724.

37. Williams RJ, Spencer JP, Rice-Evans C (2004) Flavonoids: antioxidants or signalling molecules? Free Radic Biol Med 36: 838-849.

38. Calabro ML, Tommasini S, Donato P, Raneri D, Stancanelli R, et al. (2004) Effects of alpha- and beta-cyclodextrin complexation on the physico-chemical properties and antioxidant activity of some 3-hydroxyflavones. J Pharm Biomed Anal 35: 365-377.

39. Kim SH, Choi KC (2013) Anti-cancer Effect and Underlying Mechanism(s) of Kaempferol, a Phytoestrogen, on the Regulation of Apoptosis in Diverse Cancer Cell Models. Toxicol Res 29: 229-234

40. Calderón-Montaño JM, Burgos-Morón E, Pérez-Guerrero C, López-Lázaro $M$ (2011) A review on the dietary flavonoid kaempferol. Mini Rev Med Chem 11 298-344.

41. Wang H, Khor TO, Shu L, Su Z, Fuentes F, et al. (2012) Plants Against Cancer: 
Citation: Ujowundu FN, Ukoha Al, Ojiako AO, Nwaoguikpe RN (2015) Isolation of Bioactive Phytochemicals in Leaves of Combretum dolichopentalum and their Hydrogen Peroxide Scavenging Potentials. Pharm Anal Acta 6: 444. doi:10.4172/21532435.1000444

A Review on Natural Phytochemicals in Preventing and Treating Cancers and Their Druggability. Anticancer Agents Med Chem. 12: 1281-1305

42. Batra P, Sharma AK (2013). Anti-cancer potential of flavonoids: recent trends and future perspectives. 3 Biotech 3: 439-459.

43. Tyagi E, Agrawal R, Nath C, Shukla R (2010) Cholinergic protection via alpha7 nicotinic acetylcholine receptors and PI3K-Akt pathway in LPS-induced neuroinflammation. Neurochem Int 56: 135-142.

44. Nwaoguikpe RN, Braide W, Okwu GN, Anyanwu BO, Ujowundu CO (2014) The effects of Extract of Christmas Bush (Alchornea cordefolia) on sickle cell Hemoglobin. British Journal of Pharmaceutical Research 4:158-171.

45. Elmarie van der Watt L, Pretorius JC (2001) Purification and identification of active antimicrobial properties of Mesembryanthemum crystallinum and Carpobrotus edulis extracts. Advances in Chemical Engineering and Science 2: 359-365.

46. Ibtissem B, Abdelly C, Sfar S (2012) Antioxidant and antibacterial properties of Mesembryanthemum crystallinum and Carpobrotus edulis extracts. Advances in Chemical Engineering and Science 2: 359-365.

47. Luo H, Jiang BH, King SM, Chen YC (2008) Inhibition of cell growth and VEGF expression in ovarian cancer cells by flavonoids. Nutr Cancer 60: 800-809.

48. Russo P, Frustaci A, Del Bufalo A, Fini M, Cesario A (2013) Multitarget drugs of plants origin acting on Alzheimer's disease. Curr Med Chem 20: 1686-1693.

49. Kittakoop P, Mahidol C, Ruchirawat S (2014) Alkaloids as important scaffolds in therapeutic drugs for the treatments of cancer, tuberculosis, and smoking cessation. Curr Top Med Chem 14: 239-252.

50. Cushnie TP, Cushnie B, Lamb AJ (2014) Alkaloids: an overview of their antibacterial, antibiotic-enhancing and antivirulence activities. Int J Antimicrob Agents 44: 377-386.

51. Qiu S, Sun H, Zhang AH, Xu HY, Yan GL, et al. (2014) Natural alkaloids: basic aspects, biological roles, and future perspectives. Chin J Nat Med 12: 401-406.

52. Wink M (2000) Interference of Alkaloids with neuroreceptors and ion channels. In: Atta-Ur-Rahaman (ed) Bioactive natural products. Elsevier Amsterdam 11: 3-129.

53. Manu KA, Kuttan G (2009) Immunomodulatory activities of Punarnavine, an alkaloid from Boerhaavia diffusa. Immunopharmacol Immunotoxicol 31: 377-387.

54. Sreeja S, Sreeja S (2009) An in vitro study on antiproliferative and antiestrogenic effects of Boerhaavia diffusa L. extracts. J Ethnopharmacol 126: 221-225.
55. Manu KA, Kuttan G (2009) Punarnavine induces apoptosis in B16F-10 melanoma cells by inhibiting NF-kappa B signaling. Asian Pac J Cancer Prev 10: $1031-1037$.

56. Sohni YR, Kaimal P, Bhatt RM (1995) The antiamoebic effect of a crude drug formulation of herbal extracts against Entamoeba histolytica in vitro and in vivo. J Ethnopharmacol 45: 43-52.

57. Taber's Cyclopaedic Medical Dictionary (TCMD) (1993). 17th Ed. Paris Company. Philadelphia.

58. Dillard CJ, JB German (2000) "Phytochemicals: Nutraceuticals and Human Health". Journal of Science of Food and Agriculture 80: 1744 - 1756.

59. Namkung W, Thiagarajah JR, Phuan PW, Verkman AS (2010) Inhibition of $\mathrm{Ca}^{2+}$-activated $\mathrm{Cl}^{-}$channels by gallotannins as a possible molecular basis for health benefits of red wine and green tea. FASEB J 24: 4178-4186.

60. Mittal DK, Joshi D, Shukla S (2010) Protective Effects of Polygonum bistorta (Linn.) and Its Active Principle against Acetaminophen-Induced Toxicity in Rats. Asian Journal of Experimental Biology and Science 1: 951-958.

61. Oboh G, Ekperigin MM, Kazeem MI (2005) Nutritional and Haemolytic Properties of Egg Plant. (Solanum macrocarpon) leaves. J. Food Comp. Anal 18: 153-160.

62. Ojiako OA, Ogbuji CA, Agha NC, Onwuliri VA (2010) The proximate, mineral, and toxicant compositions of four possible food security crops from southeastern Nigeria. J Med Food 13: 1203-1209.

63. Gulcin I, Oktay M, Kirecci E, Kufrevioglu OI (2003) Screening of anti- oxidant and antimicrobial activities of anise (Pimpinella anisum $\mathrm{L}$ ) seed extracts. Food Chem 83: 371 - 382.

64. Duh PD, Tu YY, Yen GC (1999) Antioxidant activity of water extract of Harng Jyur (Chrysanthemum morifolium Ramat). Lebnesmittel- Wissenschaft und technologies 32: 269-277.

65. Yu L, Haley S, Perret J, Harris M, Wilson J, et al. (2002) Free radical scavenging properties of wheat extracts. J Agric Food Chem 50: 1619-1624.

66. Ross EM, Kenakin TP (2001) Pharmacodynamics, Mechanism of drug action and relationship between drug concentration and effect. In Goodman and Gilman's The Pharmacological Basis of Therapeutics, Vol. Tenth J.G. Hardman and L.E. Limbird, Eds McGraw-Hill. New York.

67. Kenakin T (2004) Principles: receptor theory in pharmacology. Trends Pharmacol Sci 25: 186-192. 